\title{
Place and Space: Ecological Reading on Selected Gun-Aajav Ayuzana's Poems
}

\author{
Kristiawan Indriyanto \\ Sanata Dharma University
}

\begin{abstract}
Contemporary literary analysis nowadays gives particular concern towards the relationship between human and nature in the form of ecocriticism. Differing from previous literary paradigm which neglected the environmental aspect, this aspect is foregrounded in ecocriticism instead. Reading on ecological issue in literature can be in form of analyzing prose, poetry, and non-fiction nature writing. In this paper, the aim is more on contemporary poetry which highlights environmental issue, known as ecopoetry. Not only placing nature as the main theme of their poetry, ecopoets also try to reinterpret the relationship between human and non-human nature. Their poetry is characterized by their humility and deep regard toward nature. To further explores ecopoetry, this paper seeks to explore selected poems which were written by Gun-Aajav Ayurzana, a Mongolian ecopoet. Applying Tuanian concept of place and space, summarized by Bryson as place-maker and space-consciousness, this paper argues that Ayurzana displays both these two concepts. Ayurzana's poetry is marked by his exploration of distinctive Mongolian aspects, combined with his awareness of the spaciousness of nature.
\end{abstract}

Keywords: ecocriticism, eco poetry, place and space

\section{Introduction}

One of the trends in literature nowadays is the increasing awareness toward environmental issue with the advent of ecocriticism. Ecocriticism focuses on the relationship between literature and the physical environment, or in other word -earth centered approaches-:

Ecocriticism can be further characterized by distinguished it from other critical approaches. Literary theory, in general, examines the relations between writers, texts, and the world. In most literary theory, "the world" is synonymous with society -the social sphere. Ecocriticism expands the notion of "the world" to include the entire ecosphere. (Glotfelty, 1996, xiv)

Although many literary theorists have argued that reading of a literary text must focus also on the sociohistorical background of a text, as text is "worldly", they neglect to emphasize the relationship between the text and the ecosphere. Taking example from Edward Said, who states that reading of a text inevitably must also focuses on the historical context of its production as a text is part of the world (Said, 1975, 1-23), it can be seen that previous literary paradigm still gives more concern of the anthropocentrism point of view. Ecocriticism expands on this definition, the notion of "the world" is not only limited to the socio-historical contexts but also includes the ecosphere. Hence, ecocritical reading gives more emphasis of many matters related with nature as it is depicted in the text.

While acknowledging that ecocriticism enables literature to be viewed in new and greener light, Bryson puts forward the issue that environmentally aware poets still do not receive much attention. This issue is addressed by Bryson in his book, the West Side of Any Mountain (2005).He criticizes the fact that since ecocriticism's origin at the 1990's, ecocritical scholars have almost exclusively focusof prose and non-fictionnature writers such as Thoreau, Leopold, Dillard and Abbey, while contemporary nature poetry are until recently still relatively 
neglected. (Bryson, 2005, 1).Byrson notes that these genre of poetry, which he defines as "eco poetry" are both a continuation of nature poetry which originated since the Romantic movement and also differ from its counterpart in several ways, mainly:

(1) having an ecological and biocentric perspective recognizing the interdependent nature of the world

(2) possessing a deep humility with regard of our relationships with human and non-human nature. (Bryson, 2005, 82)

The aforementioned quotes illustratethat contemporary eco poets write their poems from biocentric, not anthropocentric perspective. Nature is the main concern of their poetry, furthermore they also try to reinterpret the relationship between humanand non-human. Defined by Relph as "environmental humility" (Relph, 1981, 168), eco poets humbly acknowledge that it is nature who is the master, instead of the other way around. Hence, their poetry is characterized by their modesty and reverent tone towards the goodwill of nature. To further illustrate how eco poetry reflects these perspectives, this paper analyzes several poems written by Ayurzana, a Mongolian poet.

A brief introduction of Ayurzana and his works is necessary here. Ayurzana is native Mongolian, graduated from Maxim Gorky Literary Institute in Russia. He is quite prolific writer, not just write poetry but he also delves in prose. His first novel, the Illusion (2003) received the Altan Oed literary prize from the Mongolian government and later published as a trilogy with The Debt of Ten Dreams (2005) and Born of Echo (2007). His most well-known work is his novel The Legend of the Shaman (2010) which is rewarded as the best Mongol literary work in 2000-2010 by Goo Maral Academy of Mongolia. While he is more noted for his novel achievement, he is also an accomplished poet, all of his selected poems were published under the title "Meditations" in 2013. His poetry mainly talks about the close connection Mongolian have with nature and it is loaded with awe and reverence toward nature. This paper analyzes several of his poems which have been translated into English.

\section{Methodology}

To analyze selected poems by Ayurzana, this paper applies Yi-Fu Tuan's concept of place and space, summarized by J.Scott Bryson in his book, the West Side of Any Mountain (2005). Bryson believes that there are two major concerns of ecopoets:

(1) to create place, making a conscious and concerted effort to know the more-than-human world around

us; and (2) to value space, recognizing the extent to which that very world is ultimately unknowable (Bryson, 2005, 8)

Place is defined by Tuan as "enclosed and humanized space" (Tuan in Byrson, 2005, 9). In his example, a neighborhood begins as an abstract concept for the new inhabitant. It is only after s/he interacts and become accustomed with its citizens that the vague construct begins to be identified, recognized, and eventually become home for the new resident. Eventually, the new dweller will have a sense of belonging towards his/her new community, which is stated by Tuan as "topophilia".

Originated from the Greek roots topo- (place) and -philia (love of/for), Tuan elaborates his concept of topophilia as "the affective bond between people and place or setting." (Tuan in Bryson, 2005, 11). An individual will possess topophilia whenever s/he feels a strong emotional connection toward his/her particular place. Deriving from Tuanian's concept of topophilia, Bryson argues that ecopoets function as place-maker (Bryson, 2005. 11). Through the ecopoets' topophiliac attachment toward their particular place, ecopoets narrates their personal placein the form of ecopoetry. It is hoped that by reading ecopoetry, readers can also have similar topophiliac devotion regarding their own surroundings.

Moving into the second Tuanian concept of space, it is more abstract than place. Place can be interpreted as "domesticated space"(Tuan in Bryson, 2005, 11), there is only a small section that can be realized and grasped while space is always infinite, ungraspable. To contrast between place and space, this paper gives the example of steppe. Steppe is vast untamed land, and even though there is civilization there, it will only cover a small portion. The immense wilderness of the steppe can be compared with space, while a small cultivated section is place. Relating it with eco poetry, an ecopoet will only be able to perceive his/her own place, as human senses is limited. In Bryson's words, the more we learn about the natural world, the more we realize that there is how 
much we do not, and perhaps we will never know. (Bryson, 2005, 18). Bryson names this awareness towards the infiniteness of space as space consciousness.

Together with their function as place-maker, an ecopoet are also expected to have space consciousness. Ideally, an ecopoet should recognize the dichotomy between place and space, or in Bryson's words "the attention to the finitude of place synchronized with the boundlessness of space." (Bryson, 2005, 21). In other world, an ecopoet needs to have "topophiliac devotion" toward their own place so that their readers can experience the same feeling towards their particular place. On the other hand, ecopoets must also realize that what they express in their poetry is only a small representation of the infinite space. Expanding on this issue, Brunner argues that poetry, not just ecopoetry is caused by the overlapping contact between place and space.In his opinion, poetry is:

the problematic area that breaks into existence when the poet once again realized these two worlds [the one humans create (place) and its chaotic, unmanageable opposite (space)] as they intersect, overlie, and disrupt each other. (Brunner in Bryson, 2005, 21)

This issue is especially apt when considering Ayurzana's eco poetry. As later seen in the analysis, Ayurzana balances between his status as a place-maker with his space consciousness, his awareness and his acknowledgement of the limitless scope of nature.

\section{Discussions}

This sections concerns with the analysis of selected Ayurzana's poems. This paper examines how Ayurzana both highlights place, in from of his place-making poetry, yet he also acknowledges that his poetry can only grasp a miniscule portion of the infinite space, reflected through his space consciousness. Several Ayurzana's poems illustrate Ayurzana's perspective as an ecopoet.

The first poem analysed here is entitled Written on a book given by Chimegbaatar. The title reflects the distinctiveness of Ayurzana's poetry in which his Mongolian heritage is highlighted. We see that a person named Chimegbaatar gives Ayurzana as the poem's speaker a book. Further searching on the name Chimegbaatar reveals that Chimegbaatar is the name of the disciplinary master and a lama of the Nyingmapa (Red Stream) monastery in Ulaanbaatar, Mongolia's capital city.Hence, by knowing that Chimegbaatar mentioned in the title is a lama of a Mongolian monastery, we can see how Ayurzana as a Mongolian poet gives special concern towards his own place, in this case Mongolian Buddhism as a main theme in this poem.

Further depiction on how Ayurzana explores his status as place-maker can be seen in one of the stanza of Written on a book given by Chimegbaatar. He gives emphasis towards a particular Mongolian festival named the Naadam. Naadam which means festival or feast of sports originated since the reign of Genghis Khan in the $13^{\text {th }}$ century.Rhode explores how:

Naadam, or more fully Eriin Gurvan Naadam, the 'Three Games of Men' is a specifically and distinctively Mongolian festival.... The Naadam Games are the combination of the three sports of wrestling, archery and horseracing performed either simultaneously or sequentially, according to detailed rites and rules. They are highly stylized and imbued with symbolic meaning congruent with ancient Mongolian nomadic, shamanic and hunting practices. (Rhode, 2009, 11)

Relating with how it is depicted in Ayurzana's poetry, he particularly underlines the close connection Mongolian people have toward their mount, horses. In her research, Yazdzik argues how horse is still very significant in the present day lives of many Mongolian, not just for transportation but also for entertainment (horse racing) and also their produce. (Yazdik, 2011, 4). Relating with Ayurzana's poetry, he highlights how the Naadam festival involves many horses:

The Naadam had ended, and

The grass was fading.

The wind had picked up, and

Hearts were aching.

The horses, exhausted,

Headed back towards the horizon.

I peered in their direction, 
These horses, indistinct. (Ayurzana, 2007, 7)

Through this aforementioned stanza which deals with the aftermath of the Naadam festival, Ayurzana reflects how horses is appreciated in Mongolian society. The speaker gives concern toward the wellbeing of the horses, by mentioning how the horses are "exhausted". Resembling how human are overburdened after hard day working, the horses are also tired after the Naadam festival.Ayurzana uses repetition, repeating the word "horses" in the last line of the second stanza. Still concerned with the condition of the horses, the speaker /peered in the horses' direction/, only to find out that the horses are already faraway, "indistinct" from the speaker's view.

Relating with the issue of ecopoet as a place-maker, Ayurzana's topophiliac devotion can be seen in how he expands on the two main themes relating with Mongolian culture, the Naadam festival and the special status of horses in Mongolian society. Naadam festival is the most important festival in Mongolia, which had been held for hundreds of years. Horses features prominently in this event, such as in horse-riding competition. Furthermore, the speaker expresses distress toward the exhausted state of the horses after the festival. From these highlighted aspects, we can see therefore how distinctive Ayurzana's poetry is.He illustrates his domesticity in form of his Mongolian heritage, culture, and tradition as a foregrounding theme.

After analysing Ayurzana as a place-maker through his poetry, this paper highlights Ayurzana's spaceconsciousness. This view is reflected in his same poem, written on a book given by Chimegbaatar, especially on the last stanza:

Led on a loose rein

Along faint tracks, and

A grasshopper leafs,

Splashing dew.

And on they traveled... (Ayurzana, 2007, 7)

A possible danger in the ecopoet's function as a place-makeras stated by Byrson is how the poet can be tempted to imagine that the poet is the owner or even as the creator of place. (Bryson, 2005, 18). Instead of perceiving himself as the owner of his place, Ayurzana in the previous stanza shows his humility and respect toward nature, especially horse as domesticated animals. The speaker states that the horses are /led on a loose rein/.Instead of forcing human's will toward animal, the speaker of this poem gives freedom and leeway toward the horses as an important animal in Mongolian culture.

Furthermore, the aforementioned stanza also reflects Ayurzana's space consciousness. Symbolically, Ayurzana employs the voyage of the horses across the steppe to illustrate the vastness of space. In the two lines from the previous stanzas, Ayurzana mentions:

I peered in their direction,

These horses, indistinct.

The horses are unable to be seen by the speaker due to the horses' faraway proximity from the speaker's position. The speaker is only able to vaguely guess the shape of the horses. From this paper' perspective, these lines, also the last line of this poem /and on they traveled/, reflects the spaciousness of nature, especially the Mongolian steppe. Through the closing line of the poem written on a book given by Chimegbaatar, the speaker invites the reader to imagine the journey of the horses through the vastness of Mongolian landscape.

Another poem which highlight both Ayurzana's status as place-maker and his space-consciousness is entitled Eastern Poem. In this poem, Ayurzana reflects his topophiliac affection towards Mongolian wilderness and also his awareness and recognition of the spaciousness of space. The poem is depicted here:

Such happiness

To see the sunrise on the steppe!

When I feel its calm light

I forget my sorrow. 
To breathe such air,

be human is enough!

Oh...

After that, let God take his brush

And write that I'm dying.

Such truth

To hear a branch breaking somewhere (Ayurzana, 2007, 3)

Explore firstly on the issue of place and place-maker, Ayurzana's domesticity can be seen on how the speaker of this poem is blissful whenever s/he is able to see /the sunrise on the steppe/.Ayurzana celebrates the fact that Mongolian people are still able to experience steppe's sunrise, furthermore also "the calm light" and "the air" in steppe environment. This poem's jubilant tone highlights Ayurzana's topophiliac devotion, he considers that the beautiful atmosphere in the steppe is something which should be captured and memorized in the form of poetry.

Moving into the issue of space-consciousness, Ayurzana shows his reverent and humble attitude toward nature. He describes how /be human is enough/ if he is able to experience the beautiful and healthy situation on the steppe. Able to breathe clean air and see the morning sunrise is a wonderful reminder that being human is already enough.Through his poem, Ayurzana shows a deep humility with regard of the relationship between human and nonhuman nature. It is not human who control the environment, but nature itself and also God.He proclaims that, "to breathe such air, be human is enough." He is grateful that the symbiosis between Mongolian people and nature is still quite strong, how nature gives fresh air to better the life of people there. Nature can survive without people, on the contrary people cannot survive without nature.

Another significant aspect regarding the spaciousness of space is in the last line of this poem, /to hear a branch breaking somewhere/. This line illustrates the vastness of space, in this case the Mongolian steppe. The speaker is unable to perfectly identify the exact place where the branch break, and the speaker is only able to vaguely describes it as "somewhere." It indicates how the speaker's limited human sense cannot possible be aware of everything which occurs in the steppe interior. Hence, through this line Ayurzana acknowledges that human's spatial awareness is finite, while the full extent of space is infinite.

\section{Conclusions}

It can be stated therefore how Ayurzana as an ecopoet displays both his status as place-maker and also his space consciousness, recognition of the infinite reach of space. As place-maker, Ayurzana highlights his topophiliac affection in formclose connection with his Mongolian culture, heritage, and tradition, reflected through his poems. This is seen in several ways concerning his ecopoetry, he describes the Naadam festival, how Mongolian people are depended and also concerned with the wellbeing of horses as their mount. Furthermore, his gratefulness towards the steppe environment of Mongolia is manifested in his other poem Eastern Poem.He praises the beneficial effect of the Mongolian steppe towards the people living there.

Relating with his space-consciousness, Ayurzana shows his awareness of the spaciousness of space. Through the last line of written on a book given by Chimegbaatar, /and on they travelled/, and also the closing line of Eastern Poem /to hear a branch breaking somewhere/, he illustrates the vast notion of space, which is symbolically shown by how Ayurzana invites the reader to imagine the Mongolian steppe together with the horses and where the speaker in Eastern Poem humbly admits the limited spatial perception of humanity. To summarize, the analysis explores how in Ayurzana's ecopoetry, he both displays his space-consciousness combined with his status as a place-maker.

\section{References}

[1] C.Glotfelty and H. Fromm.The Ecocriticism Reader: Landmark of Literary Ecology. Athens, U.S.A: University of Georgia Press, 1996, Introduction. pp. xiv. 
[2] D. Rhode, "Mongolia's Naadam Festival past and present in the construction of national identity," M.A. thesis, Dept of Anthropology. Eng., University of Cantenbury., Christchurch, New Zealand. 2009.

[3] E. Replh,Rational Landscapes and Humanistic Geography. London, U.K: Croom Helm Ltd, 1981. ch. 7 pp. 163.

[4] E. Yazdzik, (Spring 2011). The Mongolian Horse and Horseman. Independent Study Project (ISP) Collection. Paper 1068. pp. 1-34. Available: http://digitalcollections.sit.edu/cgi/viewcontent.cgi?article=2074\&context=isp_collection

[5] E. Said, "The Text, the World, and the Critic", The Bulletin of the Midwest Modern Language Association. Vol. 8. pp. 123, Autumn 1975. https://doi.org/10.2307/1314778

[6] G. A. Ayurzana (October 2007). Writing Sample. International Writing Program Archive of Residents' Work. Paper 200. pp. 1-13. Available: http://ir.uiowa.edu/iwp_archive/200

[7] J. S. Bryson. The West Side of Any Mountain. Iowa City, U.S.A: University of Iowa Press, 2005, ch.1. pp. 1-22

[8] R. L. Worden and A. M. Savada, Mongolia: A Country Study. Washington, D.C, U.S.A:Library of Congress, 1989. ch. 2 pp. 68. 